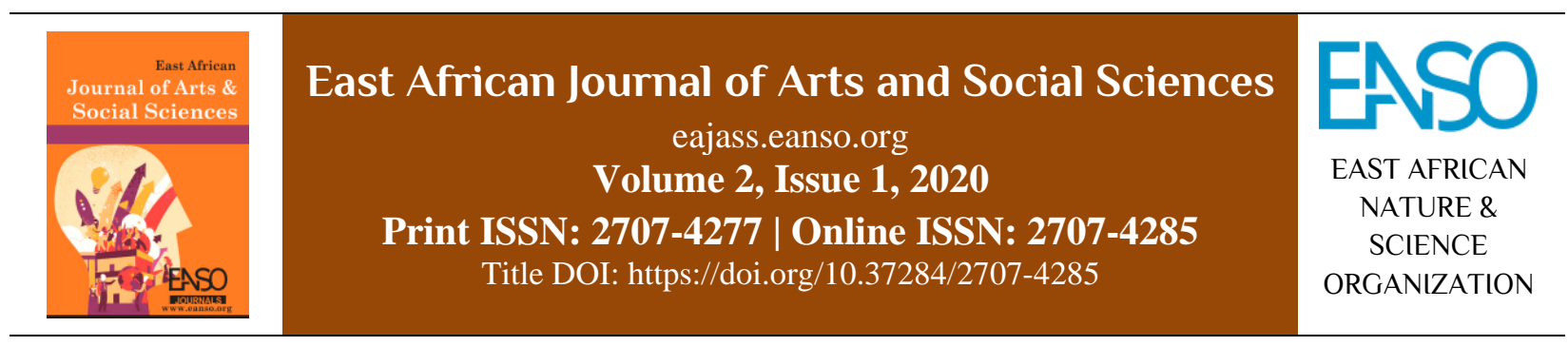

Original Article

\title{
Social Media as a Battleground for Electoral Violence among Netizens in Africa: The Case of Kenyan Youth
}

Christine W. Njuguna, $P h D^{1 *}$, Joyce Gikandi, $P h D^{2}$, Lucy Kathuri-Ogola, $P h D^{3}$ \& Joan Kabaria-Muriithi, $P h D^{4}$

${ }^{1}$ Department of Population, Reproductive Health and Community Resource Management, Kenyatta University, P. O. Box 43844 - 00100, Nairobi, Kenya; ORCID: https://orcid.org/0000-0001-71733-0498.

${ }^{2}$ Department of Educational Management and Curriculum Studies; Department of Enterprise Computing, Mount Kenya University, P. O. Box 342 - 01000, Nairobi, Kenya; ORCID: https://orcid.org/0000-0001-8531-6212.

${ }^{3}$ Department of Population, Reproductive Health and Community Resource Management, Kenyatta University, P. O. Box 43844 - 00100, Nairobi, Kenya; ORCID: https://orcid.org/0000-0002-9778-8839.

${ }^{4}$ Department of Population, Reproductive Health and Community Resource Management, Kenyatta University, P. O. Box 43844 - 00100, Nairobi, Kenya; ORCID: https://orcid.org/0000-0002-2449-0564.

*Author for Correspondence email: kristinenjuguna@gmail.com.

Article DOI: https://doi.org/10.37284/eajass.2.1.209

\section{Article history: ABSTRACT}

10 September 2020

Keywords:

Electoral Violence,

Social Media,

Youth,

Netizen,

Mathare Constituency,

Kenya.
There is a rise in unprecedented political infractions, disturbances and electoral violence in Africa with the youth playing a significant role. Thus, the study broadly investigated social media use and electoral violence among the youth in Kenya using two objectives that were to assess the use of social media platforms among the youth and to investigate the relationship between social media use and electoral violence among the youth. Guided by the Dependency Theory and the Social Responsibility Theory, the study was carried out in Mathare Constituency, Nairobi County, Kenya. Data collection involved questionnaires, key informant interviews and focus group discussions. Analysis of quantitative data was by descriptive statistics and regression while qualitative data was analyzed through transcription. The study findings showed that the use of social media platforms in communication has been growing with WhatsApp becoming the most 'preferred' platform in Kenya. The study outcome exposed the fact that social media had an important and positive effect on electoral violence among the Kenyan youth in Mathare $(\mathrm{R}=.812)$. On the other hand, social media (Facebook, WhatsApp, Twitter, YouTube and Instagram) had a strong explanatory strength on electoral violence among the Kenyan youth in Mathare $\left(\mathrm{R}^{2}=.659\right)$. This means that social media accounts for 65.9 percent of electoral violence among the Kenyan youth in Mathare Constituency, Nairobi County. 
The study, therefore, concluded that there is a relationship between social media and electoral violence among the Kenyan youth in Mathare. The study finally recommends that the government should embrace and enforce self-regulation mechanisms by Internet service providers to deter incitement. In addition, there should be increased efforts to educate and inform Internet users on the importance of assessing the credibility of information. Promotion of productive engagement as an effective instrument of dealing with online hatred is key.

\section{APA CITATION}

Njuguna, C., Gikandi, J., Ogola, L., \& Muriithi, J. (2020). Social Media as a Battleground for Electoral Violence among Netizens in Africa: The Case of Kenyan Youth. East African Journal of Arts and Social Sciences, 2(1), 104-115. https://doi.org/10.37284/eajass.2.1.209

\section{CHICAgO CITATION}

Njuguna, Christine, Joyce Gikandi, Lucy Ogola, and Joan Muriithi. 2020. "Social Media as a Battleground for Electoral Violence among Netizens in Africa: The Case of Kenyan Youth". East African Journal of Arts and Social Sciences 2 (1), $104-115$. https://doi.org/10.37284/eajass.2.1.209.

\section{HARVARD CITATION}

Njuguna, C., Gikandi, J., Ogola, L. and Muriithi, J. (2020) "Social Media as a Battleground for Electoral Violence among Netizens in Africa: The Case of Kenyan Youth", East African Journal of Arts and Social Sciences, 2(1), pp. 104-115. doi: 10.37284/eajass.2.1.209.

\section{IEEE CITATION}

C. Njuguna, J. Gikandi, L. Ogola, and J. Muriithi, "Social Media as a Battleground for Electoral Violence among Netizens in Africa: The Case of Kenyan Youth”, EAJASS, vol. 2, no. 1, pp. 104-115, Sep. 2020.

\section{MLA CITATION}

Njuguna, Christine, Joyce Gikandi, Lucy Ogola, and Joan Muriithi. "Social Media as a Battleground for Electoral Violence among Netizens in Africa: The Case of Kenyan Youth". East African Journal of Arts and Social Sciences, Vol. 2, no. 1, September 2020, pp. 104-115, doi:10.37284/eajass.2.1.209.

\section{INTRODUCTION}

The world is witnessing an explosion in the use of social media, especially among the youth amidst rampant political aggression. However, very little has been studied about the interactive relationship between social media and electoral violence among the youth. In Kenya, as in many sub-Sahara African countries, traditional media such as newspapers and radio do not appeal to the youth because they are viewed as opinionated and old fashioned. This has resulted to youth opting for social media use as an alternative for dialogue, as they have learnt that they can use this channel to shape discourse surrounding (dis)empowerment (Iwilade, 2013). The growing awareness of new media, as posited by Zuckerman (2007), however, could provide a platform for discussions among the public and information sharing. He contends that media tends to work best not in highly repressive nations but in moderately repressive ones. To this end, the assumption that there is high demand for social media in Kenya in the face of traditional media could be true and is expected to grow as long as there is excessive control on traditional print media.

The rising unprecedented political infractions, disturbances and electoral violence in Africa with the youth playing a significant role in determining the political discourse of their countries front the emerging trends (Ukeje \& Iwilade, 2012). According to Burchard (2016), sixty percent of African countries between 1990 and 2015 have experienced electoral violence attributed to incidental and structural factors. Kenya is among countries like Burundi, Cambodia, Ethiopia, Guyana, Haiti, Sri Lanka and Zimbabwe in which 
the electoral process has often become a catalyst to destructive social conflicts.

Historically, pre-election violence in the form of political rival fights and destruction of campaign materials has been rampant. The Election Day often characterized by rival fights in polling stations due to perceived fraudulent results and a manifestation of Post-Election protests have been prevalent in Kenya's elections. This may be heightened by social media interactions as much as the same platform has been used to preach peace. These general patterns of perpetration and victimization informed the need for this research. The study, therefore, broadly investigated social media use and electoral violence among the youth in Kenya using two objectives that were to assess the use of social media platforms among the youth and to investigate the relationship between social media use and electoral violence among the youth.

\section{LITERATURE REVIEW}

The study was guided by the Dependency theory proposed by Sandra Ball-Rokeach and Melvin DeFleur in 1976. The theory combines the aspects of psycho analytics and social system theory to emphasize the role of the audience in a communication process. According to this theory, there is an internal link between media, audience and the larger social system. The audience learning from the real life is limited, so they can use media to get more information to fulfil their needs. Extensive use of media generates dependence relationship in the audience. Moreover, media can create a dependence relationship with target audiences to achieve their goals by using its media power. The youth participating in the electoral process create overdependence on the available social media platforms to achieve the desire of mobilizing fellow voters. However, the theory is criticized with its limitation in showing less focus on effects.

The Dependency Theory was complemented by Social Responsibility Theory drawn from "the
Commission of the Freedom of Press" in the United States in 1949. The theory first appeared in the mid$20^{\text {th }}$ century when most of the developing countries and third world nations began to connect media to its social role (Ghosh, 2019). The theory states that there is freedom of media with self-regulation. The theory is pegged on the assumptions of the public being free to voice its opinion, recognition of community opinion, private ownership of media and media taking the social responsibility of the communications. The theory has been much used by media entities in creating professionalism by checking on the accuracy and truthfulness of information. The theory is, however, criticized through its avoidance of conflicts through acceptance of the public opinion. This relates to the problem under study on whether the acceptance of the demands of the youth during the electioneering period would end the electoral violence in urban suburbs in Nairobi.

Several existing works of literature show that there have been genuine peaceful means denoted by democratic electoral processes (Zuckerman, 2007; Fischer, 2002; O'Hare \& Moss, 2014). However, the situations in developing countries have been dominated by political power, characterized by widespread electoral violence. For instance, the Sudanese youth, despite having limited access to the democratic electoral process, gained government attention to the effect of forcing the state to enter into the greater use of social media (Kadoda \& Hale, 2015). In regard to this, in 2013, the Egyptian government had to shut down access to the Internet by its population to quell down civil 'democratic uprising' among its citizens (Yang, 2013). However, this literature fails to link the use of social media and political stability in different countries.

The literature also explains the criticism of platforms like Uwiano, PEACETXT and others that had the effect of pacifying the violence rather than providing lasting solutions to the grievances that were considered to be factors causing the people to 
fight (CIPEV, 2008). The gap in knowledge on the controversies surrounding the use of social media in sparking election violence is in the backdrop of the Sustainable Development Goals (SDGs) set by the United Nations. SDG number 16 calls for promotion of peaceful and inclusive societies for sustainable development, provide access to justice for all and build effective, accountable and inclusive institutions at all levels (United Nations, 2019). Thus, electoral violence in the context of increased use of social media undermines the target to significantly reduce all forms of violence and related death rates among the youth and especially in the city suburbs including Mathare slum in Nairobi.

\section{STUDY METHODOLOGY}

Guided by a descriptive correlation research design, the study objectives were addressed using quantitative approaches and primary as well as secondary data on social media use and electoral violence from journals and past research was collected. On specific approaches, the study investigated the nature and pattern of electoral violence among the youth. The study took place in Mathare Constituency, Nairobi County, Kenya. Mathare Constituency was one of the hotspots of 2007/2008 and recent 2017 post-election violence in Kenya. The 2019 National Bureau of Statistics (Kenya) census put Mathare at an approximate population of 206,564 of which $62 \%$ of them are aged between 18 and 35 years. Since this study had targeted the youth, the target population of the study was 128,069 . The sampling was done using Krejcie and Morgan (1970) sampling table. According to the sampling table, when the target population is over 100000 , the sample size should be 384 , hence, the study had a sample size of 384 .

In particular, it is a unique Sub-County in the Country with the highest population density of 68,941 persons per square kilometre, way far from the second populated Sub-County of Kamukunji with the population density of 25,455 persons per square kilometre. The constituency is known for its inadequacies in the provision of basic public services including water, sanitation, garbage collection, roads and footpaths, drainage, electricity and public lighting. Housing units are predominantly semi-permanent. Social amenities are inadequate, with facilities such as schools and hospitals unable to cope with the population demands. Key respondents to the survey were Kenyan youth electorate. Data was collected through the use of questionnaires, key informant interviews and focus group discussions. Quantitative data was collected from structured questionnaires and analyzed using Statistical Package of Social Sciences (SPSS) version 24.0. Descriptive statistics including frequencies such as percentages and measures of central tendency were generated. Inferential statistics significantly involved correlation and regression analyses. The presentation of findings was through the use of tables and charts.

\section{RESULTS}

\section{Demographics}

The results are based on the data collected from respondents who were youths composed of $86.9 \%$ males and $13.1 \%$ females. Other demographics were as presented in Figures 1-4 as follows.

\section{Figure 1: Age of the respondents}

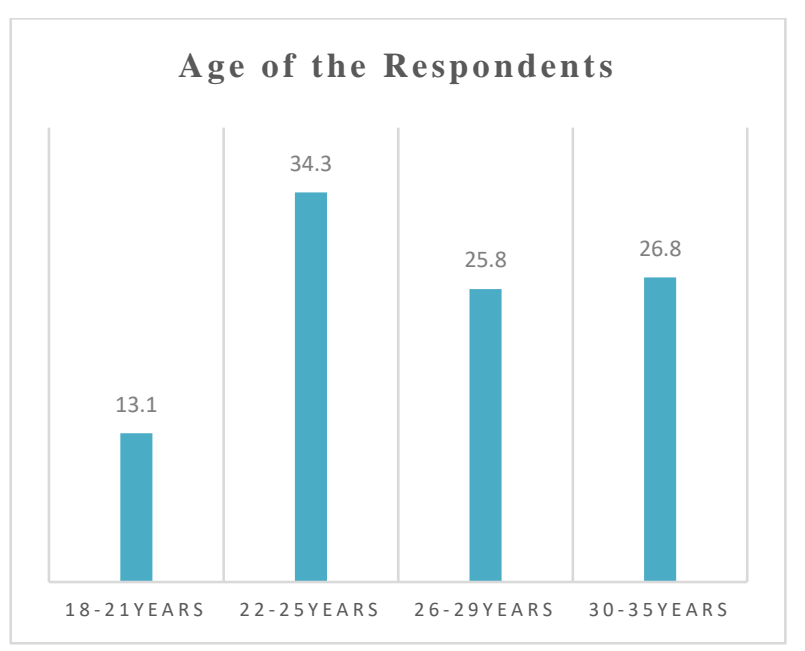


Figure 1 shows that the highest percentage of youths who participated in the study was between 22 to 25 years representing $34.3 \%$ of the respondents. Those who were between 30 to 35 years were $26.8 \%$, those between 26 and 29 years were $25.8 \%$ whereas those between 18 and 21 years were $13.1 \%$.

Figure 2: Marital Status of the respondents

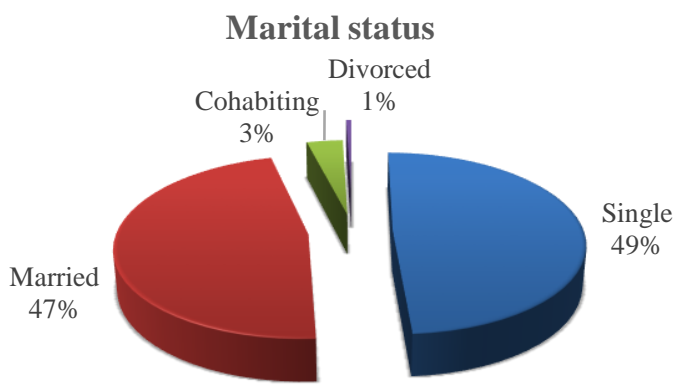

$\square$ Single $\square$ Married $\square$ Cohabiting $\square$ Divorced

Figure 2 shows that among the respondents, $49 \%$ were single, $47 \%$ being married, $3.5 \%$ cohabiting and $0.5 \%$ divorced.

Figure 3: Educational level of the respondents

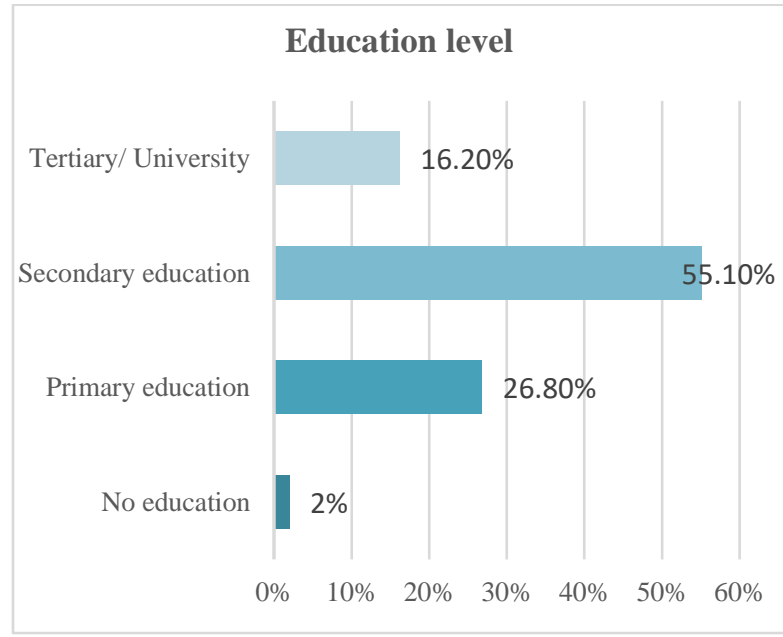

Figure 3 shows that the majority of the youths $(55.1 \%)$ had attained secondary education followed by $26.8 \%$ who had primary education. $16.2 \%$ had attained tertiary or university level education whereas $2 \%$ had no formal education.
Figure 4: Demographics of the Respondents

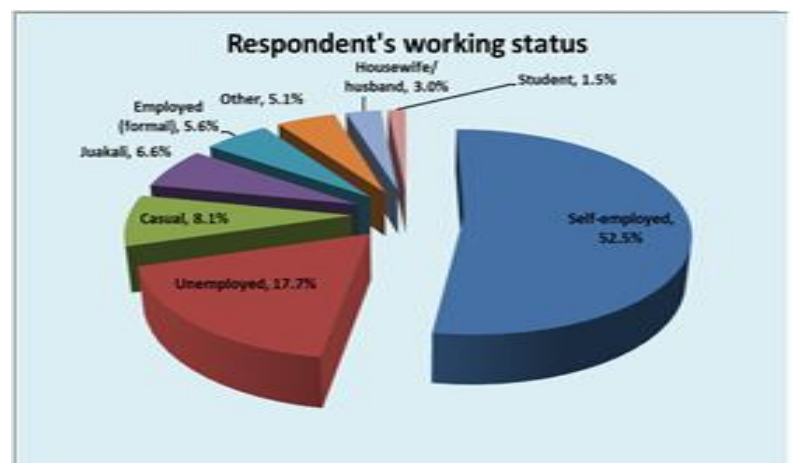

Figure 4 shows that a high proportion of respondents at 52.5 were self-employed, $17.7 \%$ were unemployed, while only $5.6 \%$ were in formal employment. In addition, $8.1 \%$ were casual workers, $6.6 \%$ worked in the informal sector, $3 \%$ were housewives or husbands and $1.5 \%$ were still in school.

Moreover, the average number of years that the respondents had stayed in Mathare was about 15 years. However, many of the respondents had been residents of Mathare for 20 years while the median time was 14 years. The respondents who had stayed for the longest time in Mathare had been there for 35 years, an indication of their residency in the area since childhood, while the respondents who had stayed for the least time had been there for less than one year. The average income for the respondents was at Kshs. 13, 462.30 with the highest income being recorded at Kshs. 120,000 and the lowest earned nothing. Most of the respondents reported earning an average income of Kshs. 10,000 per month. Overwhelming $90.4 \%$ of the youths indicated that they were registered voters with the authority to demonstrate their democratic rights during elections. Only $9.6 \%$ were not registered as voters. Out of those registered as voters, $99.4 \%$ had participated in elections while a mere $0.6 \%$ of the registered respondents had never voted.

\section{Use of Social Media Platforms among the Youth}

Through the questionnaires, the respondents were asked to indicate whether they were active users of 
social media. The findings showed that a high proportion of the sampled respondents at $89.9 \%$ were active users of social media whereas only $10.1 \%$ were passive users of social media. Kamwaria et al. (2015) associated this growth and development of social media in Kenya with an increase in the availability and speed of the internet, as well as the increase in ownership of smartphones over the last decade.

The respondents were asked how frequently they used various social media platforms. These platforms were Facebook, WhatsApp, Twitter, YouTube and Instagram. The study found out that pertaining to Facebook, almost half of the respondents (49.5\%) used it frequently (every day), $29.1 \%$ used it often (at least once a week), 9.7\% were always online, $5.1 \%$ used Facebook rarely (once a month), whereas 6.6\% have never used Facebook. Regarding WhatsApp, 49\% of the respondents reported using it frequently (every day), $20.9 \%$ used the platform often (at least once a week), $10.2 \%$ were always online, $6.6 \%$ used WhatsApp rarely (once a month), while $13.3 \%$ have never used WhatsApp. Mobile and internet-based platforms that are widely used include WhatsApp, Facebook and Twitter among others. According to BAKE (2016), WhatsApp reportedly has 10 million users in Kenya, whereas according to Facebook, its users in Kenya add up to about 6.1 million. Moreover, Twitter is also one of the most widespread and commonly used social media tools in Kenya. By 2016, 2.2 million Kenyans used Twitter (BAKE, 2016). In comparison to the findings, Hall, Kearney and Xing (2018) found that study participants had passive social media use except for chats in about five times a day. Their results showed that social media use did not determine future social interactions. However, passive social media for lonely participants was associated with lower future well-being of the participant.

This informs why a high proportion of the respondents $(69.7 \%)$ reported having never used the Twitter platform. Also, $10.3 \%$ used Twitter frequently (every day), $8.7 \%$ often (at least once a week), 6.2\% rarely (once in a month) and 5.1\% were always online. On the other hand, majority of the respondents had never used either YouTube $(54.1 \%)$ or Instagram (61.2\%). However, $15.8 \%$ used YouTube often (at least once a week), 15.3\% used it frequently (every day), 9.7\% rarely (once in a month) and $5.1 \%$ were always online. Moreover, $17.9 \%$ used Instagram frequently (every day), 8.2\% used the platform often (at least once a week), 6.6\% were always online and $6.1 \%$ used it rarely (once in a month). This shows that Facebook and WhatsApp are the most used social media platforms by the respondents. In this view, WhatsApp has become the 'preferred' channel for communication in Kenya (BAKE, 2016) because more often, content shared on WhatsApp finds its way to Twitter and Facebook. The ability to send pictures and videos makes it more attractive than Short Text Messages (SMS).

In another indicator, the respondents were asked to show their frequency of using social media during elections. The findings showed that during the period of election, most of the respondents indicated daily use of WhatsApp (63.1\%) and Facebook (63.6\%). It was reported that these were commonly used due to the high number of followers and subscribers. Moreover, a higher proportion of Twitter users (46\%) and Google chat $(38.4 \%)$ reported the use of these social media platforms daily during the election period. Conversely, one-third of Google chat respondents reported having never used Google chat during elections period as was the case of $26.8 \%$ of respondents for Twitter, and 5.6\% for Facebook and WhatsApp users.

The respondents were also asked to indicate who they mostly interacted with on social media during electioneering periods. The study found that most of the youths engage with fellow youths (68\%) on social media during an election period. This was followed by $27.9 \%$ who reported to commonly 
interacting with politicians, $7.6 \%$ with agents of leaders and $2 \%$ with friends among others in social media during an election period. According to Kamwaria et al. (2015), political leaders have taken to social media to spread propaganda as well as carry out ethnic mobilization of voters, sometimes spewing hate speech and incitement. The increased spread of hateful remarks through different media, including social media, influenced the occurrence of the post-election violence in 2007/08 (CIPEV, 2008).

Out of these groups of people, it is the interaction with politicians on social media that is likely to stimulate the youth to engage in aggressive politics and/or electoral violence as reported by $56.6 \%$ of the respondents. Moreover, $27.3 \%$ reported that it is the interaction with fellow youths that is likely to stimulate them. Agents of leaders (10.1\%), bloggers (3\%), and friends (1.5\%), were also likely to stimulate youths to engage in aggressive politics and/or electoral violence.

The study investigated the purpose or use of the various identified social media platforms among the respondents. The platforms included social media platforms such as Facebook, WhatsApp, Twitter and Instagram and were used for chatting and socializing. The findings indicated that $73.3 \%$ used Facebook for chatting and socializing as well as WhatsApp (82.2\%), Instagram (56.3\%) and Twitter (53.4\%). Moreover, 20.9\% used Facebook to gain information while 5.8\% used it for entertainment. This was similar to WhatsApp where $14.8 \%$ used the platform to gain information and 3\% used it for entertainment. Moreover, 32.9\% used Twitter to gain information, $11 \%$ for entertainment, and $2.7 \%$ for catching up on politics. In addition, $22.5 \%$ used Instagram for entertainment, 18.8 used it to gain information and only $2.5 \%$ for catching up on politics. Further, YouTube was mainly used for entertainment as reported by $57.8 \%$ of the respondents. It was also used for other purposes. For example, $21.1 \%$ used it to gain information, $16.7 \%$ for chatting and socializing, and $4.4 \%$ for catching up on politics. This indicates that Twitter, YouTube and Instagram are the main social media platforms used for catching up on politics but in minor proportions.

\section{Relationship between Social Media Use and Electoral Violence among Youth}

The collected data that associate social media and electoral violence was analyzed using different statistical models as follows.

\section{Descriptive Statistics of Social Media and Participation in Electoral Violence}

Generally, there was an agreement that social media has limited or no influence on opinion related to matters elections. This was evidenced by the high proportions (percentage/number?) of respondents who reported that the platforms have never influenced them on electoral issues. At least 6 out of 10 youths indicated that the platforms did not influence their opinion on elections. Putting it into perspective, those who indicated that the social media has had no influence cited Facebook (60.6\%), WhatsApp (64.1\%), Twitter (78.8\%), YouTube (77.8\%), and Instagram (84.4\%). However, there were small proportions of respondents whose thoughts were influenced by social media on matters related to elections. Cumulatively, $11.6 \%$ (reporting often and every time) of the Facebook users were often influenced by information from the platform on election matters. On the same note, $10.6 \%$ indicated that WhatsApp influenced their thought on matters elections. This was the case with $7.0 \%$ of Twitter users, $6.5 \%$ of YouTube users and $4.5 \%$ of the Instagram users as shown in Table 1. 
East African Journal of Arts and Social Sciences, Volume 2, Issue 1, 2020

Article DOI: https://doi.org/10.37284/eajass.2.1.209

Table 1: Influence Social Media on Electoral Violence

\begin{tabular}{llllll}
\hline & Never & Rarely & Sometimes & Often & Every time \\
\hline Facebook & 60.6 & 4.1 & 23.7 & 7.1 & 4.5 \\
WhatsApp & 64.1 & 3.5 & 21.7 & 6.2 & 4.5 \\
Twitter & 78.8 & 2.5 & 11.6 & 4.1 & 3.0 \\
YouTube & 77.8 & 4.5 & 11.2 & 4.5 & 2.0 \\
Instagram & 84.3 & 2.1 & 9.1 & 2.5 & 2.0 \\
\hline
\end{tabular}

\section{Correlation Analyses of Social Media and} Electoral Violence

Further analysis revealed that there were correlations between youth participation in electoral violence in Mathare and the frequent use of social media platforms. The following are the results from correlation analysis pitting the use of various social media platforms against the participation in electoral violence.

Table 2: Correlation analysis Results for Social Media and Electoral Violence

\begin{tabular}{|c|c|c|c|c|c|c|c|}
\hline & & 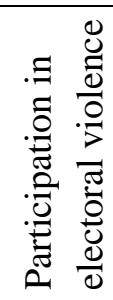 & $\begin{array}{l}\frac{1}{0} \\
8 \\
0 \\
0 \\
0 \\
\tilde{I} \\
4 \\
0 \\
0 \\
0 \\
0\end{array}$ & 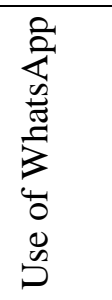 & 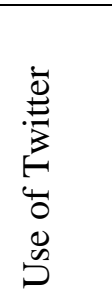 & 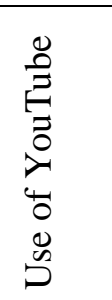 & 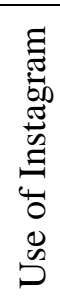 \\
\hline Electoral violence & Pearson Correlation & 1 & & & & & \\
\hline Use of Facebook & $\begin{array}{l}\text { Pearson Correlation } \\
\text { Sig. (2-tailed) }\end{array}$ & $\begin{array}{l}.632^{* *} \\
.000\end{array}$ & 1 & & & & \\
\hline Use of WhatsApp & $\begin{array}{l}\text { Pearson Correlation } \\
\text { Sig. (2-tailed) }\end{array}$ & $\begin{array}{l}.546^{* *} \\
.000\end{array}$ & $\begin{array}{l}.633^{* *} \\
.000\end{array}$ & 1 & & & \\
\hline Use of Twitter & $\begin{array}{l}\text { Pearson Correlation } \\
\text { Sig. (2-tailed) }\end{array}$ & $\begin{array}{l}.423^{* *} \\
.000\end{array}$ & $\begin{array}{l}.359^{* *} \\
.000\end{array}$ & $\begin{array}{l}.347^{* *} \\
.000\end{array}$ & 1 & & \\
\hline Use of YouTube & $\begin{array}{l}\text { Pearson Correlation } \\
\text { Sig. (2-tailed) }\end{array}$ & $\begin{array}{l}.618^{* *} \\
.000\end{array}$ & $\begin{array}{l}.541^{* *} \\
.000\end{array}$ & $\begin{array}{l}.466^{* *} \\
.000\end{array}$ & $\begin{array}{l}.241^{* *} \\
.001\end{array}$ & 1 & \\
\hline Use of Instagram & $\begin{array}{l}\text { Pearson Correlation } \\
\text { Sig. (2-tailed) }\end{array}$ & $\begin{array}{l}.461^{* *} \\
.000\end{array}$ & $\begin{array}{l}.402^{* *} \\
.000\end{array}$ & $\begin{array}{l}.290^{* *} \\
.000\end{array}$ & $\begin{array}{l}.574^{* *} \\
.000\end{array}$ & $\begin{array}{l}.265^{* *} \\
.000\end{array}$ & 1 \\
\hline
\end{tabular}

**. Correlation is significant at the 0.01 level (2-tailed).

\section{Regression Analysis and Hypotheses Testing}

The study was on the relationship between the use of social media (Facebook, WhatsApp, Twitter, YouTube and Instagram) and electoral violence among the Kenyan youth in Mathare Constituency, Nairobi County. To ascertain the relationship between the use of social media and electoral violence among the Kenyan youth in Mathare Constituency, the study used correlation and regression analysis. The aggregate mean score of electoral violence among the Kenyan youth was regressed against the aggregate mean scores of individual social media. The pertinent outcome is as shown in Table 3. 
East African Journal of Arts and Social Sciences, Volume 2, Issue 1, 2020

Article DOI: https://doi.org/10.37284/eajass.2.1.209

Table 3: Regression Results for Social Media and Electoral Violence

Model Summary

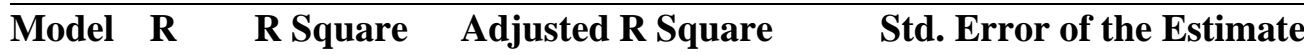

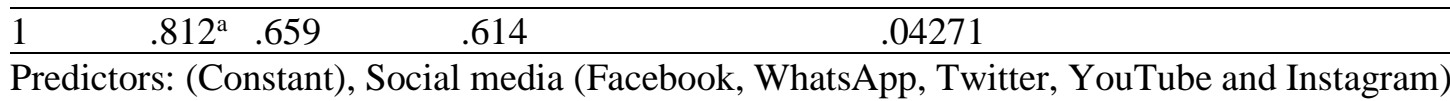

From the Model summary table, the outcomes were found to accounts for 65.9 percent of electoral revealed that social media had an important and positive effect on electoral violence among Kenyan youth in Mathare $(\mathrm{R}=.812)$. Social media had a strong explanatory strength on electoral violence among the youths in Mathare variations since they violence among the youths in Mathare change $\left(\mathrm{R}^{2}\right.$ $=.659)$. The ANOVA outcomes of social media against electoral violence among the Kenyan youths are presented in Table 4.

Table 4: Regression ANOVA Results for Social Media and Electoral Violence

ANOVA

\begin{tabular}{llllll}
\hline & Sum of Squares & Df & Mean Square & F & Sign. (p-value) \\
\hline Regression & 5.205 & 5 & 1.041 & 4.392 & .001 \\
Residual & 62.532 & 264 & .237 & & \\
Total & 67.737 & 269 & & & \\
\hline
\end{tabular}

a. Predictors: (Constant), Social media (Facebook, WhatsApp, Twitter, YouTube and Instagram)

$b$. Dependent Variable: Electoral violence

The ANOVA results revealed that social media (Facebook, WhatsApp, Twitter, YouTube and Instagram) had an overall effect on electoral violence among the Kenyan youths in Mathare and the effect was statistically significant ( $\mathrm{p}$-value = .001). Study outcomes revealed that Social media (Facebook, WhatsApp, Twitter, YouTube and Instagram) had an overall important influence on electoral violence since the overall p-value was .001 which was less than .05. The ANOVA outcomes showed that the F-ratio was greater than one $(\mathrm{F}=4.392)$ indicating that the prediction capability of the model contribution of Social media (Facebook, WhatsApp, Twitter, YouTube and Instagram) to electoral violence was significant. This has the implication that the model can meaningfully predict change in electoral violence among Kenyan youth in Mathare. Individual, ANOVA outcomes exhibited that influence of Social media (Facebook, WhatsApp, Twitter, YouTube and Instagram) on electoral violence among Kenyan youth in Mathare was significant in that $\mathrm{p}$-value was $<.05$ ( $\mathrm{p}$-value $=$ .001). The coefficients outcomes for Social media (Facebook, WhatsApp, Twitter, YouTube and Instagram) against electoral violence among Kenyan youth in Mathare are displayed in Table 5. 
East African Journal of Arts and Social Sciences, Volume 2, Issue 1, 2020

Article DOI: https://doi.org/10.37284/eajass.2.1.209

Table 5: Regression Coefficients Results for Social Media and Electoral Violence

Coefficients

\begin{tabular}{|c|c|c|c|c|c|}
\hline & \multicolumn{2}{|c|}{ Unstandardized Coefficients } & \multirow{2}{*}{$\begin{array}{l}\text { Standardized } \\
\text { Coefficients } \\
\text { B }\end{array}$} & \multirow[t]{2}{*}{$\mathbf{T}$} & \multirow[t]{2}{*}{ Sign. (p-value) } \\
\hline & Beta & Std. Error & & & \\
\hline (Constant) & 2.472 & .293 & & 8.436 & .002 \\
\hline Facebook & .634 & .176 & .401 & 3.602 & .001 \\
\hline WhatsApp & .548 & .196 & .300 & 2.795 & .000 \\
\hline Twitter & .423 & .198 & .178 & 1.136 & .000 \\
\hline YouTube & .608 & .183 & .369 & 3.322 & .003 \\
\hline Instagram & .461 & .178 & .212 & 2.589 & .000 \\
\hline
\end{tabular}

Dependent Variable: Electoral Violence

The model factor indicators show that social media measures (Facebook, WhatsApp, Twitter, YouTube and Instagram) all had important contribution to the coefficient model of electoral violence among Kenyan youth in Mathare $(t=8.436, \rho<.05)$. The model parameters in the coefficient table indicate that whenever Facebook is used as a predictor, it influences the model significantly more than any other indicator of social media $(\mathrm{t}(1.96)=3.602, \rho$ $<.001)$. In addition, the predicting strength of WhatsApp in the coefficient model was likewise important $(\mathrm{t}(1.96)=3.602, \rho<.05$. $)$. When Twitter is used as a predictor, its contributing strength to the model is meaningfully important $(\mathrm{t}(1.96)=1.136$, $\rho<.000)$ while YouTube and Instagram both have $(\mathrm{t}(1.96)=3.322, \rho<.003$.$) and (\mathrm{t}(1.96)=2.589, \rho$ $<$.000.) respectively.

Individual, coefficients outcome displayed that all measures of social media (Facebook, WhatsApp, Twitter, YouTube and Instagram) had important and positive stimulus on electoral violence among the Kenyan youths in Mathare as follows; Facebook had a positive influence on electoral violence among Kenyan youth in Mathare $(\beta=.634$ and $p$ value $=.001)$. YouTube had positively affected electoral violence among Kenyan youth in Mathare $(\beta=.608, p$-value $=.003)$. WhatsApp, on the other hand, had a positive influence on electoral violence among Kenyan youth in Mathare $(\beta=.548$, $p$-value $=.000)$. Instagram and Twitter both had significant effects on electoral violence among the Kenyan youths in Mathare with $(\beta=.461, \mathrm{p}$-value $=.000)$ and $(\beta=.423$, $p$-value $=.000)$, respectively.

From the coefficients table outcomes, the resultant regression equation that may be used to forecast level of electoral violence among Kenyan youth in Mathare for a single standard deviation enhancement in social media (Facebook, WhatsApp, Twitter, YouTube and Instagram) could be stated as shown in equation 1 :

$$
\mathrm{EV}=2.472+.634 \mathrm{FB}+.608 \mathrm{YT}+.548 \mathrm{WA}+.461 \mathrm{IG}+.423 \mathrm{TT}+\varepsilon
$$

Where:
$\mathrm{EV}=$ electoral violence among Kenyan youth in Mathare
$2.472=y$-intercept constant
$.634 \mathrm{FB}, .608, .548, .461, .423=$ the slope coefficient
$\mathrm{FB}=$ Facebook

$$
\begin{aligned}
& \text { YT }=\text { YouTube } \\
& \text { WA }=\text { WhatsApp } \\
& \text { IG = Instagram } \\
& \text { TT = Twitter } \\
& \varepsilon=\text { Error term }
\end{aligned}
$$




\section{CONCLUSION}

The study found out that social media has an important and positive effect on electoral violence among the Kenyan youths in Mathare $(\mathrm{R}=.812)$. Applications including Facebook, WhatsApp, Twitter, YouTube and Instagram had a strong explanatory strength on electoral violence among the Kenyan youths in Mathare variations. These applications were found to account for 65.9 percent of electoral violence among Kenyan youths in Mathare change $\left(\mathrm{R}^{2}=.659\right)$. This means that social media accounts for 65.9 percent of electoral violence among Kenyan youth in Mathare Constituency, Nairobi County while the remaining 34.1 percent is accounted for by other factors in the study. The study outcomes also revealed that social media (Facebook, WhatsApp, Twitter, YouTube and Instagram) had an important and positive effect on electoral violence among Kenyan youth in Mathare ( $p$-value <.05). The findings conform to the postulation of the Dependency Theory which shows the role of the voting youth in a communication process where the internal link between media, audience and large social system is depicted. Social media usage is attributed to getting more information to fulfil needs. In relation to the Social Responsibility Theory, the social media usage confirms the postulation to freedom of media with self-regulation on assumptions that the public is free to say their opinion; there is recognition of community opinion, private ownership of media and media taking the social responsibility of the communications.

The study, therefore, concludes that there is a relationship between social media and electoral violence among the Kenyan youth in Mathare. The findings conform to Becker and Copeland's (2016) revelation that there was a significant interaction between connective social media use and political interest among LGBT Americans. However, this is contrary to the findings of Goldsmith (2014) who found that there is potential for peaceful elections in many African countries including Kenya regardless of other existing factors. For Harish and Toha (2017), electoral violence varies in different ways based on the target victims, violence timing and specific locality. Pre-election violence is also likely to be within separatist areas while spreads faster after elections in ethnocommunal areas irrespective of the socialization that takes place within the population.

Based on the study outcomes that exposed that social media had an important and positive effect on electoral violence among the Kenyan youth in Mathare, this study recommends that the government should put more emphasis on handling social media during the election period since this study found out that social media (specifically Facebook, WhatsApp, Twitter, YouTube and Instagram) had a strong relationship and effect on electoral violence among the Kenyan youths in Mathare. Enforcement of regulatory laws and promotion of productive engagement as a way of handling online hatred should be encouraged by the government. This recommendation is also noted by Alkiviadou (2018).

\section{ACKNOWLEDGEMENTS}

The authors appreciate the support from the participants in this research.

\section{AUTHORS' CONTRIBUTIONS}

All authors participated in the research process from research conception to the development of research tools, data collection, analysis and writing of the research report.

\section{REFERENCES}

Alkiviadou, N. (2018). Hate speech on social media networks: Towards a regulatory framework? Journal of Information \& Communications Technology Law, 28(1), 19-35.

Ball-Rokeach, S. J., \& DeFleur, M. L. (1976). A dependency model of mass-media effects. 
Communication Research, 3(1), 3-21. doi:10.1177/009365027600300101.

Becker, B. A., \& Copeland, L. (2016). Networked publics: How connective social media use facilitates political consumerism among LGBT Americans. Journal of Information Technology \& Politics, 13(1), 22-36.

Bloggers Association of Kenya (BAKE). (2016). State of the Internet in Kenya, Bloggers Association of Kenya, www.ifree.co.ke/reports/

Burchard, B. (2016). Electoral Violence in SubSaharan Africa: Causes and Consequences. African Affairs, 115 (461), 766-767.

Commission of Inquiry into the Post-Election Violence (CIPEV). (2008). Report of the Commission of Inquiry into the Post-Election Violence. Nairobi: Government Printer.

Goldsmith, A. A. (2014). Electoral Violence in Africa Revisited. Journal of Terrorism and Political Violence, 27(5), 818-837.

Ghosh, B. N. (2019). Dependency Theory Revisited: Routledge: ISBN 978-1-315-187389.

Hall, A. J., Kearney, W. M., \& Xing, C. (2018): Two tests of social displacement through social media use. Journal of Information, Communication \& Society, 22(10), 1396-1413.

Harish, P. S. \& Toha, R. (2017). A New Typology of Electoral Violence: Insights from Indonesia. Journal of Terrorism and Political Violence, 31(4), 687-711.

Iwilade, A. (2013). Crisis as Opportunity: Youth, Social Media and the Renegotiation of Power in Africa. Journal of Youth Studies, 16(8), 1054-1068.
Kadoda, G., \& Hale, S. (2015). Contemporary youth movements and the role of social media in Sudan. Canadian Journal of African Studies/Revue canadienne des études africaines, 49(1), 215-236.

Kamwaria, A., Kamau, J. M., Githaiga, A. J., Guantai, P. M., Mugwe, R., Makin, K. R., \& Dida, G. B. (2015). Socialising Government: Evaluating the Role of Social Media in Governance and Ethics in Kenya. International Journal of Humanities and Social Science, 5(1), 117-122.

Krejcie, R.V., \& Morgan, D.W. (1970): Determining Sample size for research activities. Educational and psychological measurement 30(3)

O'Hare, A. and Moss, N. (2014). Staging democracy: Kenya televised presidential debates. Journal of Eastern African Studies, $8(1), 78-92$. doi.org/10.1080/17531055.2013.869929

Ukeje, C., \& Iwilade, A., (2012). A Farewell to Innocence? African Youth and Violence in the Twenty-First Century. International Journal of Conflict \& Violence, 6(2), 339-352.

United Nations (2019). Independent Group of Scientists appointed by the Secretary-General, Global Sustainable Development Report 2019: The Future is Now - Science for Achieving Sustainable Development, United Nations, New York.

Yang, M. (2013). The collision of Social Media and Social Unrest: Why Shutting Down Social Media is the Wrong Response. Northwestern Journal of Technology and Intellectual Property, 11(7), 708-728

Zuckerman, M. (2007). Sensation Seeking and Risky Behavior. Washington, DC: American Psychological Association. 